\title{
Komunikasi Gambar Bercerita pada Buku Belajar Baca Anak Taman Kanak-Kanak
}

\author{
Luna Setiati, Priyanto Sunarto \& Pindi Setiawan \\ Fakultas Seni Rupa dan Desain, Institut Teknologi Bandung \\ Bandung 40132, Indonesia \\ Email: bumilimas@cheerful.com
}

\begin{abstract}
Abstrak. Kejadian komunikasi rupa yang terjadi antara gambar dan anak adalah peristiwa yang perlu dialami bersama jauh sebelum anak Taman Kanak-kanak (TK) belajar baca. Tiap unsur rupa di gambar memiliki hubungan sebab akibat yang menghubungkan sebuah peristiwa. Kejadian komunikasi bersama menunjukkan kekuatan bahasa rupa dalam menyampaikan pesan secara aktif atau ketika mereka bekerja sama. Kejadian ini memberi kesempatan gambar untuk mengirim pesan secara aktif dan membiasakan anak menangkap pesan dan menuturkan pesan dari gambar yang ditatapnya.

Penelitian ini mengangkat pentingnya peran gambar bercerita dalam kejadian komunikasi rupa bersama anak. Penelitian ini menghasilkan tiga model komunikasi gambar dengan seluruh unsur rupa dan cara kerjanya berdasar indikator berbahasa rupa-kata anak. Dinamika pada model komunikasi ini menunjukkan sejauh mana peran pendamping (orang tua dan guru) dalam memotivasi dan memfasilitasi terjadinya interaksi antara gambar dan anak secara mandiri. Penelitian ini membuktikan pentingnya aktivitas anak menatap gambar dilakukan jauh sebelum anak bisa membaca tulisan. Penelitian ini sekaligus menunjukkan pentingnya dua fungsi utama gambar bercerita sebagai pembawa pesan aktif dalam menatap gambar dan fungsi gambar sebagai penjelas tulisan dalam belajar baca.
\end{abstract}

Kata Kunci: model komunikasi gambar; menatap gambar bercerita; bahasa rupa anak.

\begin{abstract}
Visual communication event that happen between picture and preschool children should happen in cohesion event before the children learning to read. Each visual element in the picture has causal relation which links the event together. This cohesion shows the power of visual language not only in sending a massage independently but also in working together. This event will give a change for the picture in sending a massage actively and give the children a habit in capturing the meaning and telling the story they gaze from the picture. This research enhanced the important role of storytelling picture in visual communication event with preschool children together. The results of this research are three models of picture communication with their visual elements and how they work based on children visual-word language. The dynamics of visual communication have placed the role of tutors (parents and teachers) in motivating and facilitating children in gazing the picture independently. This
\end{abstract}


research show the important event of visual communication between storytelling picture and children far before they learn to read through the book. This research also indicates the two main functions of storytelling picture as an active messenger in gazing the picture and as an explanatory word in learning to read.

Keyword: picture communication model; gazing the storytelling picture; children visual language.

\section{Pendahuluan}

Cara anak melihat dan menggambar memang berbeda dengan orang dewasa yang hidup di jaman modern. Cara ini berpegaruh terhadap cara mereka menggambar dan termasuk menatap gambar. Tidak semua gambar memiliki bahasa rupa yang sama dengan kemampun anak menggambar. Tidak semua cara pendampingan dapat memotivasi keluarnya bahasa rupa pada gambar anak atau pada saat anak menatap gambar. Kemampuan anak dalam menatap gambar dapat dilihat melalui kemampuan anak mengkonstruksi unsur rupa dan menuturkan pesan dari gambar. Tiap kejadian komunikasi gambar membutuhkan sistem dalam menyampaikan dan menerima pesan dengan cara kerjanya yang khas. Jenis gambar ini disebut gambar bercerita yang menggunakan sistem bahasa rupa anak.

Ada dua persoalan dasar seputar komunikasi gambar bercerita yang berawal dari apa yang diketahui dan yang belum diketahui para pendidik anak usia dini (PAUD). Kejadian komunikasi gambar bercerita dan kecemasan orang tua dan guru terhadap persiapan anak membaca sebelum masuk SD. Alasan yang ada dibelakang persoalan tersebut dapat diketahui melalui hasil kuesioner yang dikembalikan sekitar 90 orang tua murid dan 28 guru dari empat Taman Kanakkanak (TK) yang seluruh siswanya sebanyak 205 anak terlibat pada penelitian ini.

Sekitar $98 \%$ orang tua dan semua guru menyatakan setuju bahwa aktivitas anak menatap gambar penting dilakukan jauh sebelum anak bisa membaca kata. Yang menarik adalah alasan dibalik pernyataan mereka, yaitu $51 \%$ orang tua dan 54\% guru beralasan gambar penting untuk membantu anak belajar membaca tulisan. Hasil kuesioner tesebut menunjukkan bahwa orang tua dan guru lebih mengenal fungsi gambar pada buku belajar baca anak TK untuk belajar membaca dibanding menatap gambar.

Sebenarnya perbandingan antara mereka yang mengganggap gambar penting untuk aktivitas anak menatap gambar dengan yang menjelaskan tulisan tidak terlalu signifikan. Tetapi yang perlu diteliti adalah mencari jenis gambar yang 
mampu mendorong anak lebih mudah dalam bertutur dan berpotensi dalam mengembangkan cerita berdasarkan bahasa rupa yang digunakan gambar.

Hasil kuesioner diatas menunjukkan kecemasan orang tua terhadap kesiapan anak membaca sebelum usia SD lebih tinggi daripada kemampuan anak mentatap gambar. Minimnya pengetahuan para guru, orang tua, dan penggambar dalam penggunaan gambar bercerita pada buku belajar baca anak TK. Fakta diatas termasuk belum masuknya indikator berbahasa rupa anak pada kurikulum PAUD di Indonesia menyebabkan terabaikannya fungsi gambar bercerita sebagai aktivitas anak menatap gambar pada buku belajar baca anak. Fungsi gambar akhirnya hanya dikenal untuk menjelaskan tulisan dibanding fungsi mandirinya membawa pesan (Gambar 1).

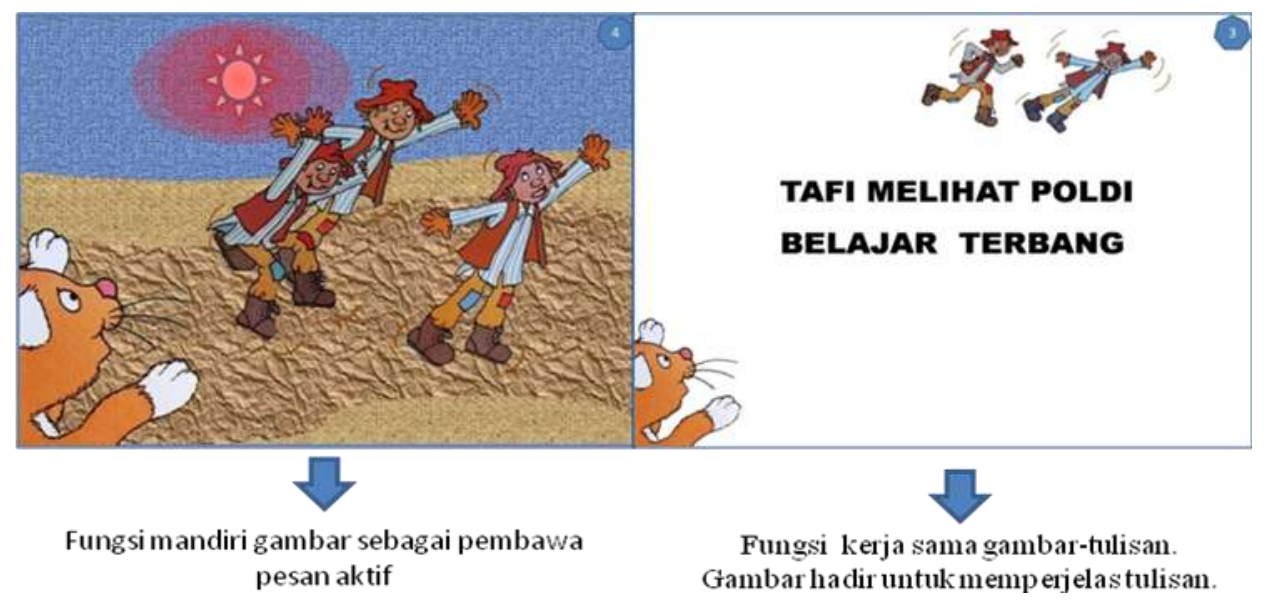

Gambar 1 Dua fungsi gambar pada buku belajar anak TK.

Penelitian ini menunjukkan sejauh mana pentingnya kejadian komunikasi rupa bagi anak dan bagaimana gambar dengan bahasa rupa anak yang khas menjalankan dua fungsinya sekaligus, yaitu sebagai pembawa pesan mandiri termasuk sebagai penjelas tulisan. Keuntungan bagi anak adalah membina kemampuan berpikir dan berbahasa rupa-kata anak. Aktivitas ini melatih imajinasi dan kreativitas anak dalam mengkonstruksi unsur rupa menjadi pesan yang dipahami dan menuturkannya jauh sebelum ia bisa membaca. Keuntungan bagi gambar adalah gambar memiliki daya dorong dalam memotivasi gaya tutur anak sesuai usia perkembangan bahasa rupa-kata.

\section{Pengamatan Respon Anak dan Analisa Cara Wimba}

Mengidentifikasi unsur rupa dan cara kerja unsur rupa ketika menyampaikan pesan dalam sebuah kejadian komunikasi rupa dapat dilakukan dengan dua cara. 
Pertama, mengamati respon anak menatap gambar. Kedua, menganalisa cara gambar.

Analisa cara gambar digunakan untuk mencari dan memilih gambar yang dapat memenuhi kriteria anak menatap gambar. Respon anak diamati dan dicatat berdasarkan cara anak bertutur. Isi ceritanya kemudian menjadi data yang siap diolah menjadi unsur rupa dan cara kerjanya. Hubungan antara gaya tutur dan isi pesan yang dituturkan anak dengan unsur rupa dan cara kerjanya membawa penelitian ini pada strategi dan cara pendampingan anak ketika menatap gambar.

Evaluasi yang dilakukan pendamping dan proses verifikasi guru menunjukkan pentingnya standar perkembangan berbahasa anak, dimulai dari indikator bahasa rupa anak menatap gambar dan bahasa kata anak dari mendengar dan berbicara.

Indikator berdasarkan standar kompetensi di kurikulum pendidikan anak usia dini Indonesia Departemen Pendidikan Nasional [1] menyebutkan anak TK B mampu membaca sampai 5 susunan kata, tapi tidak disebutkan indikator kemampuan anak bertutur dari menatap gambar dan indikator bahasa rupa anak ketika menatap gambar.

Oleh karena itu membandingkan perkembangan bahasa rupa anak ketika anak menggambar dan ketika anak menatap gambar perlu dilakukan untuk menentukan indikator bahasa rupa anak yang terabaikan dalam kurikulum pendidikan anak usia dini Indonesia maupun dalam gambar yang selama ini beredar pada buku belajar baca.

Perkembangan bahasa rupa anak sesuai tahapan usianya adalah hasil penelitian Tabrani [2] dari analisa cara gambar anak dan gambar orang dewasa jaman pendahulu (sebelum jaman modern). Standar perkembangan bahasa rupa anak dari aktivitas menggambar ini kemudian diadaptasi dan disesuaikan untuk kebutuhan aktivitas anak menatap gambar pada penelitian ini. Penelitian ini menemukan tahapan kejadian komunikasi gambar bersama anak TK. Mulai dari jenis gambar yang digunakan anak menatap gambar sampai membaca tulisan. Penelitian ini menemukan standar jumlah adegan dalam satu layar dan jumlah halaman yang mampu ditatap anak sampai pada tahap mengenalkan hubungan gambar dengan kata dan kalimat.

\section{$3 \quad$ Tiga Sudut Pandang Penelitian}

Ada tiga sudut pandang penting dalam melihat persoalan kejadian komunikasi gambar bercerita. Pertama, sudut pandang kejadian komunikasi rupa untuk 
memastikan terjadinya peristiwa komunikasi rupa antara anak dan gambar sesuai indikatornya. Kedua, sudut pandang penggunaan gambar dan kritik penggunaan gambar pada buku belajar baca. Ketiga, sudut pandang cara belajar dan berpikir rupa anak untuk mengetahui sejauh mana kemampuan anak dalam melakukan aktivitas menangkap unsur perupaan dari sebuah gambar.

Ketiga sudut pandang diatas memiliki peran dalam melihat hubungan antara kejadian komunikasi, gambar bercerita dan buku belajar baca anak TK. Fokus penelitian ini berada pada persoalan komunikasi yang terjadi antara gambar dan anak. Dari sudut pandang gambar, kemampuan gambar dalam menyampaikan pesan melalui unsur rupa dan cara kerjanya menunjukkan pentingnya peran bahasa rupa anak ketika berkomunikasi rupa dengan anak.

Sudut pandang pertama menjelaskan perbedaan mazhab komunikasi yang melibatkan gambar. Pengetahuan tersebut memperjelas prinsip dasar kejadian komunikasi gambar bercerita yang perlu direpresentasikan dalam bentuk model. Model ini menjadi hasil penelitian yang dapat digunakan para penatap dan pendamping serta pihak lain yang membutuhkan. Alternatif model komunikasi rupa diperlukan untuk menerangkan proses komunikasi gambar pada aktivitas anak menatap gambar. Proses komunikasi antara gambar yang menyampaikan pesan dan kemampuan anak menguraikan dan menuturkan unsur rupa saat menatap gambar dapat menjelaskan cara komunikasi gambar sekaligus memberikan pengetahuan sejauh mana fungsi pendampingan mampu memotivasi kemandirian anak berinteraksi dengan gambar.

Sudut pandang kedua menunjukkan dampak penggunaan bahasa rupa anak oleh gambar bercerita dan bahasa rupa orang dewasa oleh cerita bergambar yang digunakan pada buku belajar baca anak TK. Kekuatan bahasa rupa anak pada gambarlah yang memungkinkan anak mampu menatap gambar secara mandiri. Kekuatan itu ada pada unsur rupa yang digunakan gambar saat berkomunikasi rupa.

Sudut pandang ketiga menunjukkan strategi dan cara pendampingan anak dalam menentukan kemandirian kejadian komunikasi gambar bercerita antara gambar dan anak. Sewajarnya anak mampu menatap gambar jauh sebelum ia membaca tulisan. Persamaan antara menatap gambar dan membaca adalah pada kemampuan menangkap pesan. Dengan demikian keberhasilan proses anak menatap gambar secara mandiri bergantung dari cara anak belajar menangkap pesan berdasarkan bentuk pendampingannya. 


\subsection{Perbedaan Mazhab Komunikasi}

Ada dua mazhab yang menjadi landasan penting sebelum menentukan posisi kejadian komunikasi gambar bercerita. Pemetaan ini penting untuk melihat sejauh mana peran gambar bercerita dalam kejadian komunikasi yang mendorong terjadinya kemandirian anak dan gambar dalam aktivitas konstruksi unsur rupa menjadi pesan sampai penuturan pesannya.

Fiske menyebutkan perbedaan kedua mazhab ini dalam bukunya Cultural Communication Studies [3]. Mazhab pertama adalah model komunikasi yang memposisikan gambar sebagai media komunikasi antara pengirim dan penerima. Mazhab kedua adalah model yang memposisikan gambar sebagai pelaku aktif komunikasi rupa dengan anak sebagai penatap gambar.

Perbandingan antara kedua mazhab dalam memahami proses pengalihan informasi menegaskan perhatian yang selama ini luput pada model komunikasi alih pesan selama ini, yaitu potensi gambar sebagai objek imaji berbahasa rupa dan potensi penatap gambar yang menangkap pesan dengan kemampuan bahasa rupa yang dimilikinya.

Mazhab pertama melihat komunikasi sebagai transmisi pesan, sering disebut sebagai alih pesan [3]. Beliau mencontohkan beberapa model komunikasi alih pesan, seperti model Gerbner, Shanon dan Weaver.

Mazhab kedua melihat komunikasi sebagai produksi dan pertukaran makna, sering disebut alih makna. Mazhab ini tidak memandang kesalahpahaman sebagai bukti penting kegagalan komunikasi. Mazhab ini sering disebut alih makna [3]. Beliau menggunakan semiotika sebagai pisau bedah mazhab ini. Contoh bahasa rupa yang digunakan pada mazhab alih makna ini adalah Peirce dan Saussure.

Peristiwa komunikasi gambar bercerita memang tidak melibatkan penggambar secara langsung saat terjadinya kejadian bersama tersebut. Pendamping yang hadir secara fisikpun tidak terlibat langsung, ia hanya berperan sebagai motivator dan fasilitator anak yang bertanggung jawab terhadap kemandirian kejadian komunikasi bersama tersebut.

Dengan demikian kedua sudut pandang mazhab diatas menunjukkan dua hal. Mazhab alih pesan menunjukkan pentingnya sebuah pesan melalui gambar dapat ditangkap oleh pembacanya dengan memiliki bahasa rupa yang sama antara gambar dan penatap gambar. Dalam konteks ini gambar dianggap sebagai media. 
Sementara mazhab alih makna menunjukkan pentingnya penggunaan bahasa rupa sebagai sistem komunikasi pada kejadian komunikasi gambar bercerita ini. Dalam konteks ini gambar bukan lagi media, tetapi ia adalah pembawa pesan aktif dan anak adalah pengkonstruksi pesannya. Kehadiran pendamping adalah memastikan terjadinya kemandirian kejadian komunikasi gambar bercerita (Gambar 2).

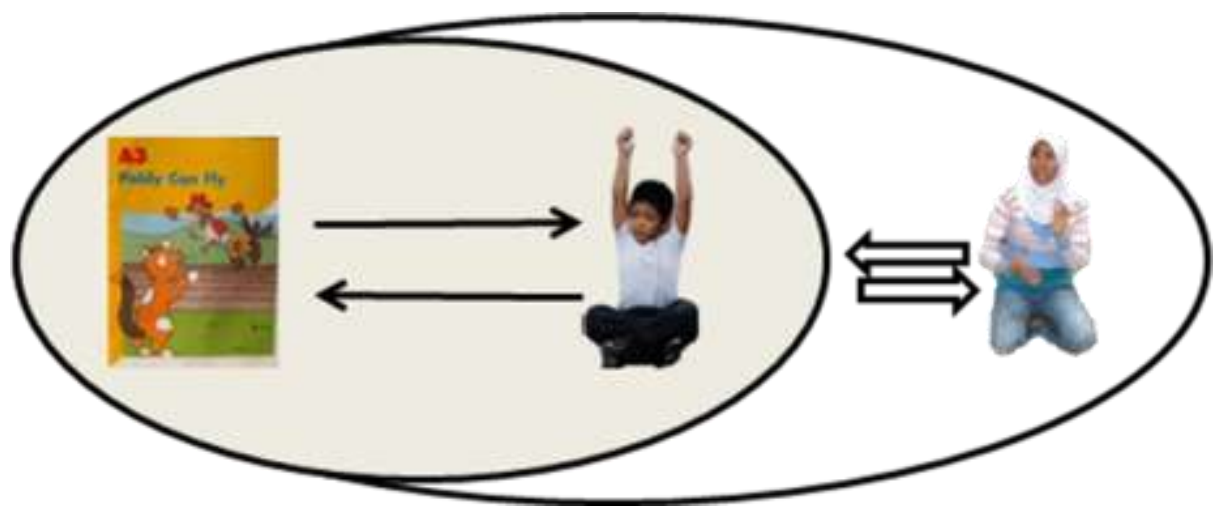

Gambar 2 Model komunikasi gambar bercerita yang menempatkan gambar, penatap gambar dan pendamping dalam kejadian komunikasi bersama. Panah dua arah menunjukkan interaksi pada tiap area, area gambar dan anak, area gambar-anak dengan pendamping.

\subsection{Bahasa Rupa}

Tabrani [4] menegaskan bahwa bahasa yang digunakan pada proses belajar di Indonesia masih fokus pada bahasa kata belum bahasa rupa. Arnheim [5] menyebutkan, bahwa kesalahan dunia barat selama ini adalah telah membiarkan gambar tidak layak dianggap sebagai bahasa, karena membayangkan tidak dianggap sebagai proses berpikir.

Tabrani [2] menemukan dua sistem bahasa rupa. Bahasa rupa adalah sistem komunikasi yang penting pada kejadian komunikasi gambar bercerita. Perbedaan sistem bahasa rupa inilah yang menentukan cara kerja tiap jenis gambar. Dua jenis gambar dengan jenis bahasa rupanya disebut gambar bercerita dan cerita bergambar. Kedua jenis gambar inilah yang digunakan pada penelitian.

Gambar bercerita memiliki cara berbeda dalam menyampaikan pesannya dengan cerita bergambar. Gambar bercerita adalah jenis gambar yang memiliki alternatif cara gambar dalam menyampaikan pesannya. Gambar bercerita memiliki cara kerja khas yang tidak sama seperti mata telanjang melihat 
sesuatu, yaitu cara menggambar peristiwa yang terjadi dalam ruang dan waktu pada bidang datar (sistem RWD).

Sistem RWD ini memungkinkan anak yang menatapnya seperti melihat sebuah film dalam imajinasi, padahal gambar yang ditatap anak berada pada bidang gambar yang datar. Ada tokoh yang bergerak dan ada waktu yang berjalan seperti layaknya menonton Kemampuan gambar dalam bercerita dapat dilihat melalui unsur rupa dan cara kerjanya berdasarkan sistem komunikasi yang hanya bisa dipahami anak dan gambar itu sendiri, yaitu bahasa rupa anak.

Komunikasi gambar bercerita adalah kejadian penting yang perlu dialami bersama oleh gambar dan anak. Bukan persoalan anak mampu menyampaikan pesan secara benar atau salah, tetapi lebih pada kejadian penemuan unsur rupa dan cara kerjanya. Inilah komunikasi gambar bercerita, yaitu ketika gambar menyampaikan pesannya dengan cara khas.

Cerita bergambar dan gambar bercerita memiliki pesan bercerita, tetapi mereka memiliki cara yang berbeda dalam menggambarkan pesannya. Sistem gambar yang digunakan pada cerita bergambar memiliki cara gambar naturalis seperti dilihat mata, digambar secara perspektif (dengan satu-dua titik hilang) dan satu waktu (moment opname). Beliau menggunakan istilah ini karena sistem ini mencandera gambar seperti apa adanya di dunia nyata. Gambar tidak berdimensi waktu (still picture) dan dipenjarakan dalam bingkai (perspektif).

Gambar 3(a) dan 3 (b) menunjukkan peristiwa yang terjadi dalam ruang dan waktu pada sebuah bidang datar. Dua adegan utama, yaitu peristiwa Tafi melihat dan Poldi jatuh diperlihatkan melalui hadirnya objek yang digambar yaitu tokoh Tafi dan Poldi dan aktivitas yang dilakukan kedua tokoh tersebut.

Perbedaan kedua jenis gambar ini adalah pada cara tiap unsur rupa yang bekerja dalam menyampaikan pesannya. Cara gambar bercerita menyampaikan peristiwa Poldi jatuh diperlihatkan dengan cara kembar, tokoh yang sama digambar berulang untuk menunjukkan gerak jatuh. Walaupun semua tokoh digambarkan dengan cara naturalis tetapi tiap objek ditata dengan cara kembar. Informasi waktu dapat dilihat melalui hadirnya ciri waktu, yaitu matahari dan bulan untuk memberi tahu bahwa kejadian Poldi jatuh berlangsung dari siang sampai malam. Unsur rupa dan cara kerjanya menunjukkan peristiwa Poldi jatuh dari tahap awal ia mencoba terbang tetapi gagal dan akhirnya jatuh.

Cara cerita bergambar menyampaikan informasi Poldi jatuh adalah dengan menggambarkan Poldi pada posisi terakhir dari kejadian yang menimpanya, yaitu jatuh dalam posisi terduduk. Dengan demikian waktu dianggap tidak berjalan saat posisi itu dibuat, seperti sebuah hasil jepretan photo. Ruang yang 
ada digambarkan dengan cara perspektif, dan semua objek digambarkan dengan cara naturalis, semua obyek digambarkan seperti dilihat mata dengan cara yang sederhana.

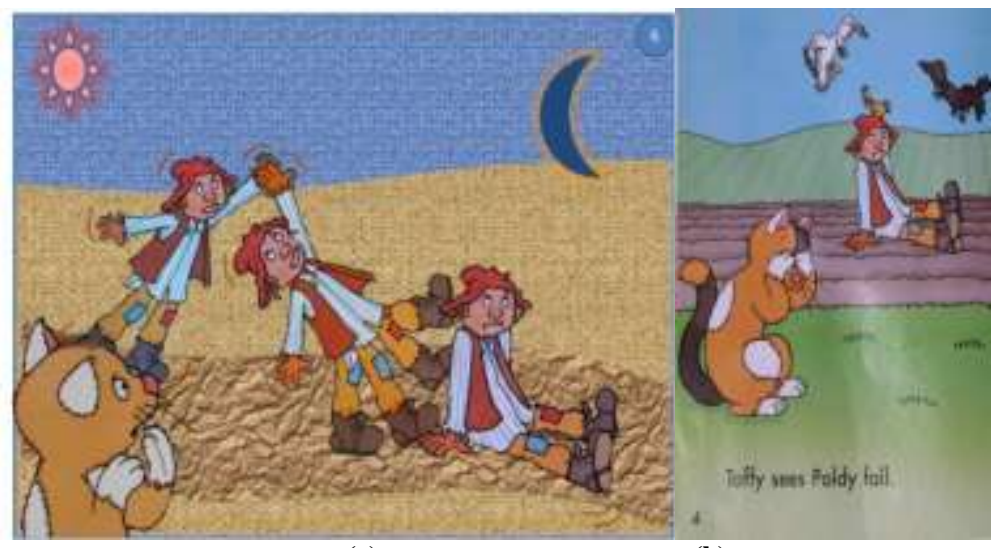

(a)

(b)

Gambar 3 Contoh gambar bercerita dan cerita bergambar.

Spesifikasi gambar bercerita dan cerita bergambar ini digunakan pada pengamatan respon anak menatap gambar. Hasilnya menjadi acuan jenis gambar yang digunakan pada tahap pengamatan berikutnya.

\subsection{Strategi dan Cara Pendampingan Anak}

Tabrani mengatakan bahwa tahapan cara anak menggambar berhubungan dengan perkembangan usia mereka. Dengan demikian sifat bahasa rupa yang dimiliki anak adalah sesuatu yang secara alamiah terjadi (nature). Menurut beliau sifat alamiah ini menempatkan posisi guru dan orang tua sebagai motivator dan fasilitator. Dengan demikian sifat pendampingan strategi yang mendorong sesuatu yang bersifat alamiah untuk keluar (nurtured).

Tidak semua perencanaan memiliki metode belajar yang mampu memfasilitasi proses kreativitas dan imajinasi anak dalam menceritakan gambar. Berdasarkan kebutuhan itulah beberapa teori belajar dikaji untuk menemukan strategi pembelajaran dan metode belajar anak dalam proses anak menatap gambar.

Pertama, Strategi Proses Belajar Proses Kreasi (SPBPK) dengan Cara Belajar Kreatif yang Integral (CBKI). Strategi dan metode itu dikembangkan dari pendidikan integral dan Limas Citra Manusia Tabrani. Konsep dan metode tersebut tidak lepas dari peran kreativitas dan imajinasi dalam proses belajar. Tabrani sendiri sudah menekankan pentingnya peran imajinasi dan kreativitas dalam proses belajar pada tesisnya tahun 1970, jauh sebelum diterbitkan 
pertama kali tahun 1974 sebagai buku kuliah di FSRD ITB dan buku bacaan ilmiah populer untuk umum tahun 2006 [6].

Kajian strategi pendampingan belajar anak yang kedua dikembangkan berdasarkan teori konstruktif, yaitu strategi pembelajaran inkuiri. Semua teori ini dikaji untuk mencari metode pendampingan anak yang tepat saat menatap gambar.

\section{Temuan Spesifik dan Umum}

Hasil Pengamatan anak menatap gambar ini dilakukan dalam tiga model komunikasi gambar. Tiap model dibagi tiga babak. Pertama, anak melakukan aktivitas awal. Kedua, anak mengkonstruksi pesan dari gambar yang ditatapnya. Ketiga, anak menuturkan pesan dari gambar. Babak dua dan tiga disebut aktivitas inti anak menatap gambar yang memposisikan pengamat sebagai pendamping.

Secara spesifik tiap model komunikasi gambar menghasikan temuan berbeda dengan perbedaan usia penatap, bentuk aktivitas awal dan tujuan. Model satu ditatap anak TK A, diawali pengenalan tokoh. Model dua ditatap anak TK B, diawali pengenalan tokoh dan cerita. Model tiga ditatap anak TK A dan TK B, diawali pemberian tugas.

Dari sisi tujuan, semua model diteliti untuk menemukan model yang dianggap bisa mewakili kejadian gambar dan anak berkomunikasi secara mandiri. Proses kemandirian tersebut disimpulkan melalui unsur cara kerja unsur rupa yang terlibat. Tujuan model pertama memastikan jenis gambar yang mampu memandirikan anak menatap gambar sesuai indikator berbahasa. Tujuan model kedua, mencari unsur rupa dan cara kerja unsur rupa pada jenis gambar bercerita ketika berkomunikasi dengan anak. Tujuan model ketiga memastikan jumlah adegan dalam tiap layar yang mampu dikonstruksi dan dituturkan anak sesuai penemuan model satu dan dua.

Temuan penelitian ini menghasilkan temuan yang bersifat spesifik dan juga umum. Temuan spesifik pada tiap model adalah sebagai berikut:

\subsection{Temuan Spesifik Model 1 (Ditatap Anak TKA)}

Model 1 diawali dengan pengenalan para tokoh cerita. Gambar pada buku belajar baca pada model ini ditatap anak TK A. Gambar yang ditatap anak menggunakan dua sistem yang berbeda untuk mencari jenis gambar yang memiliki dorongan lebih besar pada anak dalam menangkap pesn dan bertutur. Pendamping mengamati dan mencatat respon anak menangkap pesan dari 
gambar dan menuturkan pesannya. Respon itu dicatat berdasarkan indikator bahasa rupa-kata sesuai tahapan usia anak. Secara spesifik, ada tiga temuan pada model 1 ini, yaitu:

1. Kemampuan anak TK A menatap gambar adalah maksimal 1-2 adegan/ layar, dengan total 4-6 halaman. Temuan itu diperoleh melalui perbandingan waktu yang dilalui anak TK A untuk menatap gambar pada dua buku yang memiliki jumlah adegan/ layar pada total jumlah halaman yang berbeda. Pertama, gambar dengan 1-2 adegan/ layar, total 10 halaman (6 halaman buku cerita bergambar dengan 4 halaman buku gambar bercerita). Kedua, gambar dengan 2-4 adegan/ layar, total 6 halaman. Ternyata lama waktu yang dibutuhkan anak TK A untuk menatap 2-4 adegan/ layar kurang lebih dua kali lipat lebih lama dibandingkan gambar berisi 1-2 adegan/ layar.

Perbandingan waktu menatap itu dapat dilihat pada tabel 1. Tabel ini dibuat berdasarkan analisa data penuturan anak yang dicatat pada saat mengamati respon anak menatap gambar. Perhitungan itu diperoleh dari waktu yang diperlukan anak ketika menatap gambar di babak 2-3, dibagi total jumlah anak, dibagi total halaman yang ditatap anak (lihat teks yang diberi highlight abu sebagai variabel pembagi dan yang dibagi).

Tabel 1 Perbandingan 1-2 dan 2-4 adegan / layar yang ditatap anak TK A.

\begin{tabular}{|c|c|c|c|c|c|c|c|c|c|}
\hline \multirow{2}{*}{ No } & \multirow{2}{*}{$\begin{array}{l}\text { Nama } \\
\text { TK A/ } \\
\text { kelas }\end{array}$} & \multirow{2}{*}{$\begin{array}{l}\text { Jumlah } \\
\text { anak }\end{array}$} & \multirow{2}{*}{ Jam } & \multirow{2}{*}{$\begin{array}{c}\text { Total } \\
\text { halaman }\end{array}$} & \multirow{2}{*}{$\begin{array}{l}\text { Jumlah } \\
\text { adegan }\end{array}$} & \multicolumn{2}{|c|}{$\begin{array}{c}\text { Pembagian } \\
\text { waktu (dalam } \\
\text { menit) }\end{array}$} & \multicolumn{2}{|c|}{$\begin{array}{c}\text { Waktu menatap/ } \\
\text { layar }\end{array}$} \\
\hline & & & & & & $\begin{array}{c}\text { Babak } \\
\quad 1\end{array}$ & $\begin{array}{c}\text { Babak } \\
\text { 2-3 }\end{array}$ & menit & detik \\
\hline \multirow{2}{*}{1} & $\begin{array}{c}\text { Permata } \\
\text { Ayah }\end{array}$ & 15 & $\begin{array}{c}09.00- \\
11.00\end{array}$ & 10 & $1 \mathrm{~s} / \mathrm{d} 2$ & 20 & 100 & 0.67 & 40 \\
\hline & $\begin{array}{l}\text { Bunda / } \\
\text { Crab }\end{array}$ & 15 & $\begin{array}{l}09.00- \\
11.15\end{array}$ & 6 & $2 \mathrm{~s} / \mathrm{d} 4$ & 20 & 115 & 1.28 & 77 \\
\hline \multirow[b]{2}{*}{2} & Tunas & 17 & $\begin{array}{c}09.00- \\
11.14\end{array}$ & 10 & $1 \mathrm{~s} / \mathrm{d} 2$ & 20 & 114 & 0.67 & 40 \\
\hline & $\begin{array}{l}\text { Unggul/ } \\
\text { Orange }\end{array}$ & 19 & $\begin{array}{c}09.00- \\
11.50\end{array}$ & 6 & $2 \mathrm{~s} / \mathrm{d} 4$ & 20 & 150 & 1.32 & 79 \\
\hline
\end{tabular}

2. Ditemukan kelebihan gambar bercerita dalam berkomunikasi. Dari sisi gambar, gambar bercerita memiliki alternatif cara gambar lebih banyak untuk menyampaikan peristiwa yang terjadi dalam ruang dan waktu pada satu layar dibanding cerita bergambar. Terbukti dari jumlah bidang gambar yang diperlukan gambar bercerita menyampaikan pesan Poldi belajar terbang lebih sedikit daripada cerita bergambar (Gambar 4) 


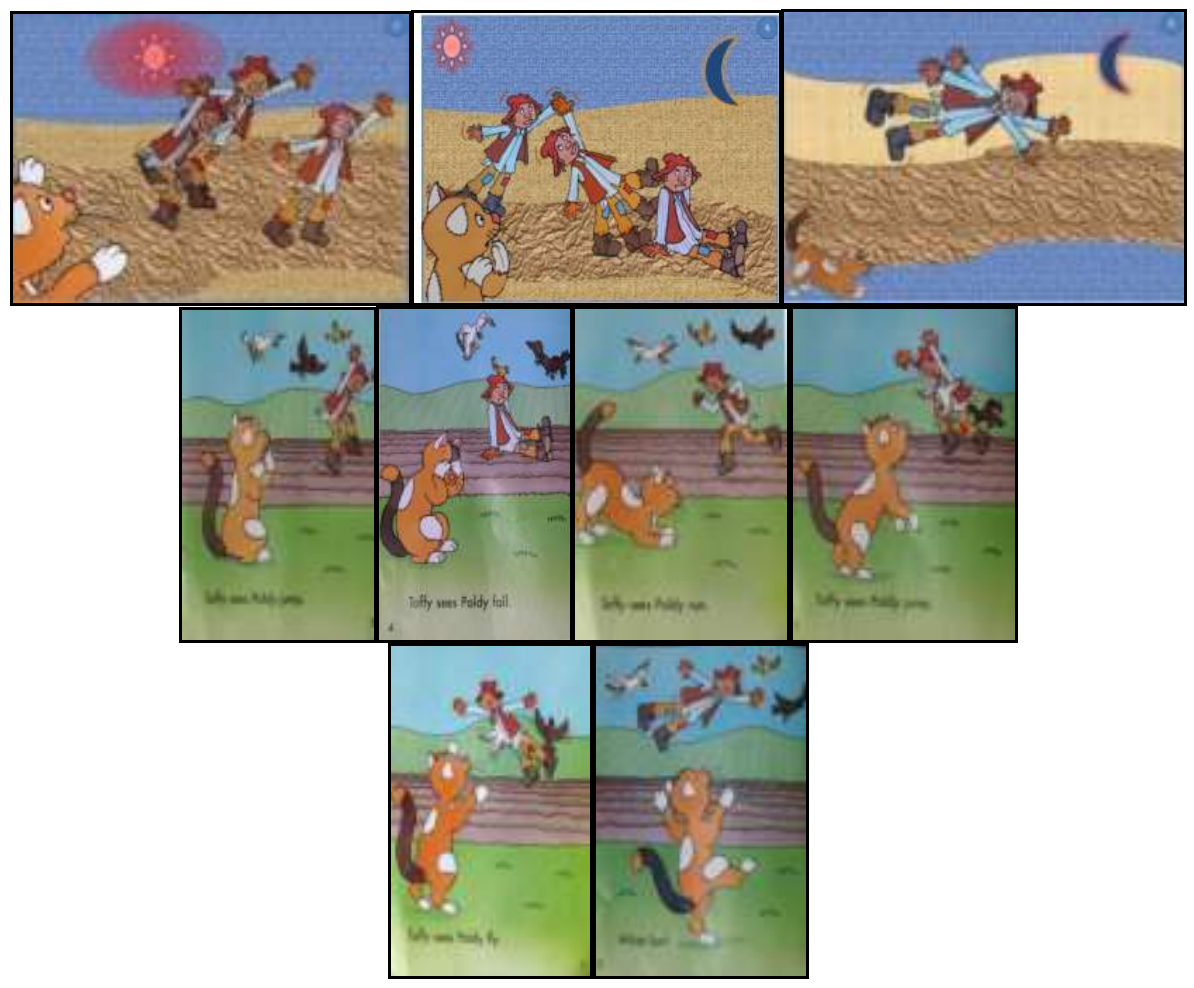

Gambar 4 (atas) gambar bercerita dan (bawah) cerita bergambar.

Dari sisi anak, hasil penuturan anak menatap gambar bercerita ternyata mengandung lebih banyak kata, daripada gambar jenis cerita bergambar. Contoh penuturan gambar IV.1 oleh Keira (TK A Gagas Ceria, Kelas Awan, 13 April 2011) pada layar 1, Tafi lihat Poldi mau terbang tapi nggak berhasil. Layar 2, Tafi lihat Poldi terbang dan jatuh. Layar 3. Tafi lihat Poldi bisa terbang.

Keira menuturkan pesan dari gambar bercerita lebih banyak daripada cerita bergambar pada gambar 4 (atas) Contoh penuturan gambar 4 (bawah) bingkai ini, Tafi lihat Poldi loncat, bingkai berikutnya Poldi jatuh, Poldi lari dan seterusnya.

Kelebihan lain gambar bercerita adalah bahwa isi pesan gambar bercerita lebih mudah diterka anak daripada isi pesan cerita bergambar. Dibuktikan dari hasil perhitungan persentase pengamatan model pertama pada 101 anak TK A. Score kecocokan antara teks tulisan dan gambar pada jenis cerita bergambar 35.31. Sementara score kecocokan antara teks tulisan dan gambar pada jenis gambar bercerita 98.76 
3. Dinamika yang terjadi pada proses komunikasi gambar terlihat pada perbedaan yang terjadi akibat pengkondisian awal. Pada model satu, aktivitas mengenalkan tokoh dilakukan di babak awal untuk memperlancar proses anak menatap gambar, mencairkan suasana agar anak merasa nyaman dan termotivasi dalam proses menatap gambar.

Dari dinamika ini ditemukan tiga gaya tutur yang bersifat umum. Pada model satu ini anak bergaya tutur sesuai standar (SS) jumlahnya sekitar 50\%. Sedangkan anak-anak yang bergaya tutur sesuai standar dan mengembangkan ceritanya (MC) sekitar $25 \%$. Sedangkan anak-anak yang mengalami kesulitan dan perlu pendampingan lebih intensif (PM) jumlahnya sekitar $25 \%$. Temuan ini menunjukkan bahwa anak bisa menangkap bahasa rupa.

Dinamika ini membawa kelebihan, kelemahan dan kesulitan dalam pelaksanaannya. Temuan ini berguna bagi para pendamping ketika melaksanakan model ini. Dinamika ini memungkinkan terjadinya komunikasi gambar bercerita bersama antara anak dan gambar.

Kelebihannya adalah membantu anak lebih cepat masuk dalam zona nyaman dan mempercepat proses berpikir anak menatap gambar. Aktivitas awal ini memfasilitasi dan memotivasi anak untuk mengenal dan mengingat nama tokoh. Kelebihan lain adalah ternyata informasi pengenalan tokoh tidak mengganggu anak menemukan sendiri cara menuturkan peristiwa dalam gambar dengan strukturnya yang khas. Misal nama yang harus dituturkan ketika anak menatap gerak Poldi mau terbang tapi jatuh lagi, tapi belum berhasil terbang. Cara menggambarkan peristiwa "belajar" adalah kosa imaji baru buat anak untuk menuturkan peristiwa tersebut.

Kelemahan dinamika pada model 1 adalah anak membutuhkan waktu dalam memikirkan nama peristiwa yang baru dikenalnya pada gambar, karena anak hanya tahu nama tokoh dan pendamping hanya boleh bertanya.

Kelemahan lain, semakin banyak anak dilibatkan dalam kelompok menatap gambar, semakin banyak anak yang memiliki kecenderungan meniru hasil tutur teman sebelumnya. Dengan demikian lebih tinggi tingkat kesulitan pendamping untuk memotivasi anak menemukan pesan dari gambar sesuai pendapatnya sendiri.

Semakin banyak jumlah anggota dalam kelompok pengamatan, semakin tinggi tingkat kegagalan anak menatap gambar. Hal itu disimpulkan berdasarkan hasil temuan waktu di lapangan. Optimalisasi rentang kosentrasi yang bisa dijaga rata-rata pada anak TK dimulai dari pengkondisian awal, aktivitas menatap gambar dalam kelompok sampai bermain dalam kelompok menunggu total 
kurang lebih 2 jam 15 menitan untuk maksimal 20 anak. Waktu yang dihabiskan anak saat menunggu giliran dalam kelompok 5 anak adalah 30 menit.

Diperlukan tingkat keahlian guru dalam menjaga kerahasiaan nama dari peristiwa yang akan ditatap anak pada gambar pada saat anak menatap gambar. Karena model ini hanya membolehkan guru mengenalkan tokoh tapi tidak memberi cerita partisipasi. Selama proses berlangsung, pendamping hanya boleh bertanya secara terarah dan bertahap agar jawaban anak terbangun sampai ingatan anak pada nama tokoh muncul kembali, tetapi tidak boleh memberi informasi yang berkaitan dengan nama peristiwa yang melibatkan tokoh cerita.

\subsection{Temuan Spesifik Model 2 (Ditatap Anak TK B)}

Babak pertama pada model ini bertujuan mencairkan suasana agar anak merasa nyaman dan termotivasi untuk terlibat dalam proses menceritakan gambar yang ia tatap. Berdasarkan tujuan tersebut, aktivitas ini diawali dengan pengenalan tokoh yang disampaikan secara partisipatif dengan melibatkan anak.

Beberapa kosa kata baru perlu dikenalkan pada anak untuk memperlancar proses anak menatap gambar. Kosa kata baru itu difasilitasi melalui cerita partisipasi untuk dijawab anak secara kolektif. Misal kata kerja mencari dan objek baru ramuan ajaib. Cerita partisipatif mengajak anak berbagi peran dan berpartisipasi dalam proses pengenalan tokoh dan cerita asal muasal empat Naga. Mulai dari tempat tokoh itu berasal, dari 4 unsur penting bumi, air, tanah, api dan udara sampai peran para tokoh yang terlibat dalam cerita itu. Tujuan utama cerita partisipasi adalah mengenalkan kosa kata baru bukan urutan peristiwa yang ada pada gambar.

Sesuai temuan kelebihan gambar bercerita melalui analisa model satu, maka jenis gambar yang digunakan pada model dua adalah gambar bercerita dominan RWD. Ada dua temuan spesifik yang tidak ditemukan di model lain. Pertama, temuan jumlah adegan yang mampu ditatap anak/ layar dengan jumlah total halaman. Kedua, temuan dinamika komunikasi di babak satu yang diawali pengenalan tokoh dan cerita awal. Temuan ini diperoleh dari pengamatan dinamika anak selama kegiatan.

1. Anak TK B mampu menatap maksimal 2-4 adegan/ layar, dengan total enam halaman. Minimal anak butuh 0.97 menit dan maksimal 1.17 menit untuk proses menatap gambar/ halaman. Pada model dua, babak satu diawali dengan pengenalan tokoh dan cerita awal. Perhitungan itu diperoleh melalui waktu yang diperlukan anak menatap gambar pada babak 2-3, dibagi total jumlah anak, dibagi jumlah total halaman yang ditatap anak. 
Tabel 2 Durasi anak TK B menatap gambar bercerita, 2-4 adegan/ layar, enam halaman.

\begin{tabular}{|c|c|c|c|c|c|c|}
\hline \multirow{2}{*}{ No } & \multirow{2}{*}{ Nama TK B/ kelas } & \multirow{2}{*}{$\begin{array}{c}\text { Jumlah } \\
\text { anak }\end{array}$} & \multicolumn{2}{|c|}{ Pembagian waktu } & \multicolumn{2}{|c|}{$\begin{array}{c}\text { Waktu menatap/ } \\
\text { layar }\end{array}$} \\
\hline & & & Babak 1 & Babak 2-3 & menit & detik \\
\hline 1 & Seqoia/ KG B & 3 & 20 & 21 & 1.17 & 70.00 \\
\hline 2 & $\begin{array}{c}\text { Permata Ayah Bunda/ } \\
\text { Octopus }\end{array}$ & 13 & 20 & 78 & 1.00 & 60.00 \\
\hline 3 & Gagas Ceria / Bumi & 15 & 20 & 80 & 0.89 & 53.33 \\
\hline 4 & Gagas Ceria/ Bulan & 17 & 20 & 105 & 1.03 & 61.76 \\
\hline 5 & Tunas Unggul/ Red & 13 & 20 & 78 & 1.00 & 60.00 \\
\hline 6 & Gagas Ceria/ Bintang & 18 & 20 & 105 & 0.97 & 58.33 \\
\hline 7 & Tunas Unggul/ Green & 7 & 20 & 45 & 1.07 & 64.29 \\
\hline \multirow[t]{2}{*}{8} & $\begin{array}{c}\text { Permata Ayah Bunda/ } \\
\text { Dolphin }\end{array}$ & 17 & 20 & 105 & 1.03 & 61.76 \\
\hline & TOTAL & 103 & & & & \\
\hline
\end{tabular}

2. Dinamika pada model dua ini menemukan bahwa dari sisi anak, jenis gambar bercerita memungkinkan anak menuturkan cerita lebih banyak ketimbang cerita bergambar. Hasil penelitian menunjukkan anak TK A-B mampu menuturkan 3-7 adegan per layar gambar dalam 1 halaman, sementara berdasarkan kurikulum Paud Indonesia, indikator tertinggi anak TK B adalah anak menyebut 4-5 urutan kata. Bila 1 adegan berisi 2 kata, misal Poldi terbang, maka dengan maksimal 7 adegan/ layar, anak mampu menuturkan total 7 x 2, yaitu 14 kata, sementara dengan membaca tulisan anak hanya mampu menuturkan maksimal 5 kata.

Contoh gambar 5 menunjukkan kemampuan Ariq TK B Gagas Ceria dalam menuturkan gambar tersebut, yaitu "Naga YU mencari Naga King di dekat pohon, jalan ke tengah lalu kalo yang Naga Yu bingung kanan atau kiri. Naga Yu sekarang cari yang dikanan akhirnya ketemu di dalam gua". Total jumlah kata yang dituturkan adalah sekitar 26 kata.

Dinamika yang terjadi pada model dua menemukan tiga gaya tutur dengan komposisi $16 \%$ anak yang perlu motivasi (PM), $33 \%$ bergaya sesuai standar (SS). Gaya tutur Ariq diatas termasuk gaya mengembangkan cerita (MC) jumlahnya pada model 2 ada sekitar $50 \%$. Total anak TK B yang diamati adalah 103. Total hasil temuan tiga gaya tutur pada model dua tersebut menunujukkan bahwa anak TK B bisa menatap gambar bercerita. 


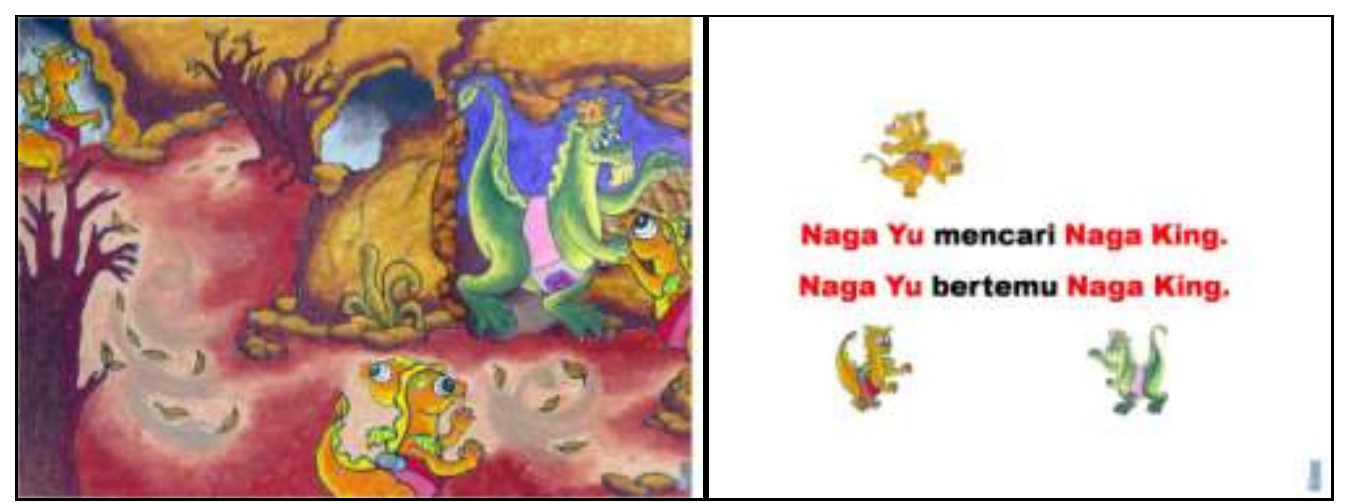

Gambar 5 Salah satu halaman gambar bercerita "Petualangan Naga Yu".

Pengenalan tokoh dan cerita partisipasi pada model dua menjadi kelebihan model dua ini, yaitu membantu anak masuk dalam zona nyaman, karena memudahkan anak memahami konteks cerita.

Perbendaharaan kata dari nama objek dan peristiwa serta aktivitas yang sering dilakukan oleh tokoh menjadi mudah diingat anak, karena dilakukan anak sendiri dalam pengalaman bersama dalam bentuk bermain partisipasi.

Kelemahannya adalah masalah waktu di babak awal. Kejadian komunikasi gambar bercerita yang diawali dengan pengenalan tokoh dan cerita bersama anak ini memakan waktu lebih lama ketimbang hanya dengan mengenalkan tokoh, yaitu sekitar 20 menit untuk pengenalan tokoh dan bercerita partisipasi. Problem akan muncul, bila aktivitas ini dilakukan secara masal, karena kemampuan anak menatap gambar tidak akan optimal terevaluasi.

Dinamika pada model dua ini juga menemukan tingkat kesulitan pendampingan. Khususnya keahlian guru dalam menjaga kerahasiaan berbahasa rupa pada saat anak menatap gambar. Karena guru hanya boleh bertanya secara terarah dan bertahap agar ingatan anak terbangun pada peristiwa atau nama tokoh yang diberikan di awal. Aktivitas di babak awal itu membantu anak memahami cerita dari gambar yang ditatapnya.

\subsection{Temuan Spesifik Model Tiga (Ditatap Anak TK A-B)}

Model ini digunakan untuk memastikan jumlah adegan yang dapat ditatap anak/ layar gambar bercerita. Berkaitan dengan hal itu, gambar bercerita yang ditatap anak pada model ini hanya berisi satu halaman, dengan jumlah total sembilan adegan/layar. 
Model ini sekaligus digunakan untuk membuktikan kemandirian anak dalam mengkostruksi pesan saat menatap gambar. Babak awal berupa pengenalan tokoh dan cerita partisipasi dikhawatirkan mengganggu proses kemandirian anak. Berkaitan dengan hal itu, model ini tidak diawali cerita maupun pengenalan tokoh.

Ada tiga temuan spesifik pada model tiga ini, yaitu:

1. Ternyata anak TK A-B mampu menatap gambar dengan jumlah adegan maksimal sampai tujuh adegan/ layar sepanjang jumlah halaman tidak lebih dari satu (Tabel 3).

Tabel 3 Kemampuan TK A-B membaca adegan/ layar.

\begin{tabular}{lccccc}
\hline & & \multicolumn{2}{c}{ Adegan/layar } & \multicolumn{2}{c}{ Durasi } \\
\cline { 3 - 5 } No & Nama TK A-B/ kelas & maks & min & Maks & min \\
\hline 1 & Seqoia/ KG A & 7 & 3 & 9 menit & 3 menit \\
2 & Seqoia/ KG B & 5 & 3 & 5 menit & 5 menit \\
3 & TK A Gagas Ceria/ Air & 7 & 3 & $4-7$ menit & $3-4$ menit \\
4 & TK B Gagas Ceria/ Bintang & 7 & 3 & $4-9$ menit & 4 menit \\
\hline
\end{tabular}

2. Temuan dinamika komunikasi yang terjadi ketika babak satu hanya diawali pemberian tugas tanpa pengenalan tokoh dan cerita awal menempatkan posisi pengamat menjadi pendamping. Strategi yang dijalankan adalah strategi pembelajaran inkuiri terpimpin. Strategi ini menempatkan pendamping dalam memotivasi kemampuan anak menemukan pesan dan menuturkan hasil temuannya sendiri sesuai dengan tingkat kesulitan anak.

3. Hasil temuan tiga gaya tutur pada model tiga menunujukkan bahwa anak TK A dan B bisa menatap gambar. Terbukti dari $53 \%$ anak bergaya sesuai standar (SS), $43 \%$ anak mampu mengembangkan cerita (MC), dan hanya $0.9 \%$ anak yang perlu dimotivasi (PM) dari total 39 anak TK A dan B (Tabel 4).

Tabel 4 Pengelompokan tiga gaya tutur di model 3.

\begin{tabular}{cccccc}
\hline & & & \multicolumn{3}{c}{ Gaya Tutur Anak } \\
No & Nama TK A-B/ kelas & Jumlah anak & SS & MC & PM \\
\hline 1 & Seqoia/ KG A & 3 & 0 & 3 & 1 \\
2 & Seqoia/ KG B & 4 & 2 & 1 & 0 \\
3 & TK A Gagas Ceria/ Air & 18 & 11 & 7 & 0 \\
4 & TK B Gagas Ceria/ Bintang & 14 & 8 & 6 & 0 \\
& TOTAL & $\mathbf{3 9}$ & $\mathbf{2 1}$ & $\mathbf{1 7}$ & $\mathbf{1}$ \\
\hline
\end{tabular}


Dari contoh perwakilan tiga gaya tutur anak pada model ini dapat dilihat hubungan antara isi penuturan dengan unsur rupanya (Tabel 5). Dari penuturan anak dapat dilihat unsur rupa yang ditangkap anak bertahap sampai pemahaman pesan. Isi penuturan Nabil, Alsya dan Zaki menunjukan pola tutur Subyek/ Predikat/ Obyek. Nama tempat (dimana) dan waktu kejadian (kapan) umumnya dituturkan anak dengan didahului pertanyaan.

Tabel 5 Contoh Penuturan, pengamatan dan verifikasi guru model 2.

\begin{tabular}{cccc}
\hline No & Nama & Isi penuturan & $\begin{array}{c}\text { Pengamatan dan Verifikasi } \\
\text { Penampilan }\end{array}$ \\
\hline 1 & Nabil & $\begin{array}{c}\text { Jack lagi merekam pedagang balon, terus } \\
\text { balonnya terbang. Ada pedagang balon, } \\
\text { terbang karena balonnya terlalu banyak. } \\
\text { Sama Jack dilemparin besi, besinya } \\
\text { dibengkokin. Lalu nempel di kaki, ada tali } \\
\text { langsung narik. }\end{array}$ & $\begin{array}{c}\text { Lancarita } \\
\text { mengembangkan cerita }\end{array}$ \\
2 & Alsya & Jono merekam orang yang lagi naik balon. & Lancar \\
3 & Zaki & Rangga buat film orang lagi terbang sama \\
balon. & $\begin{array}{c}\text { Kosa imaji dan adegan } \\
\text { kurang, Sering dimotivasi }\end{array}$ \\
\hline
\end{tabular}

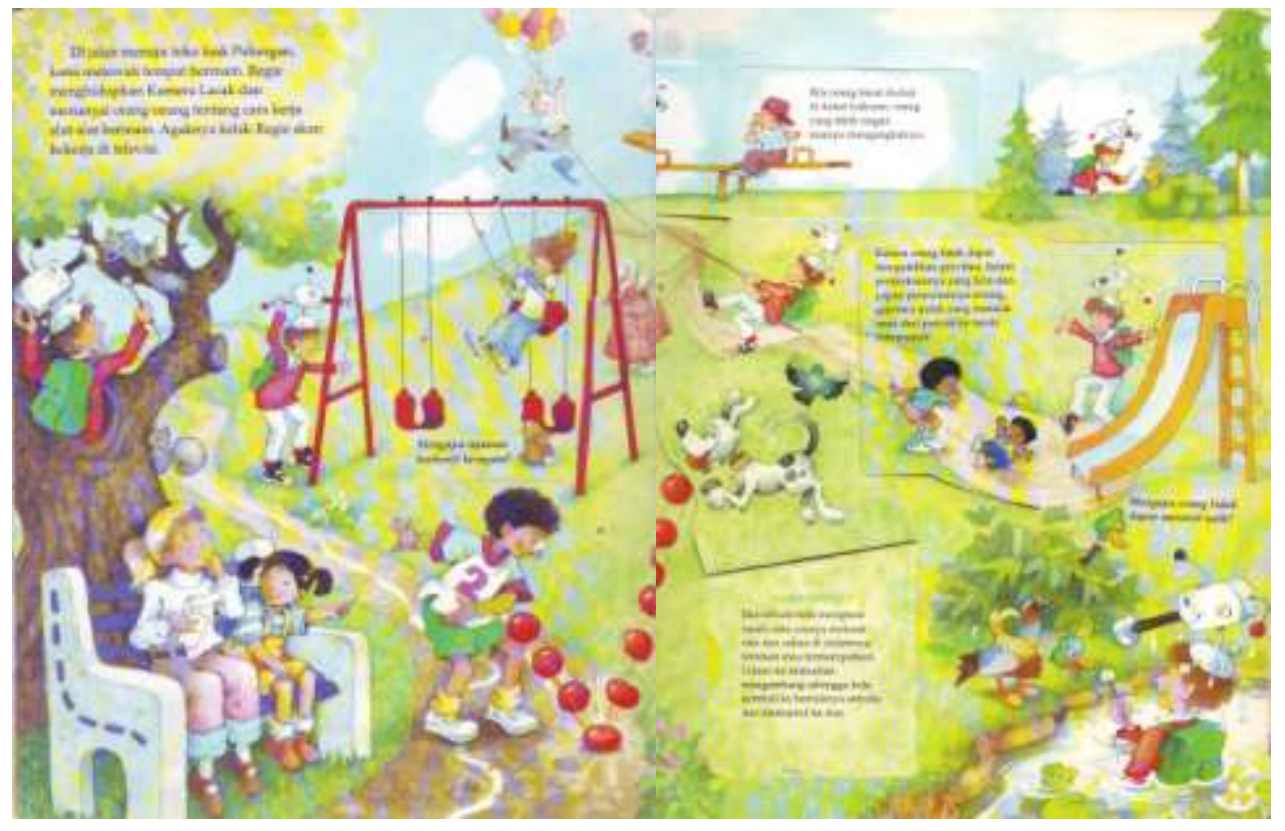

Gambar 6 Teks rupa dan kata pada gambar model tiga. 


\subsection{Temuan Umum dari Tiga Model Komunikasi}

Secara umum semua kejadian komunikasi gambar menghasilkan lima temuan, yaitu:

1. Temuan unsur rupa dan cara kerjanya. Didapat dari pengamatan struktur kata saat anak bertutur dan struktur rupa saat anak mengkonstruksi pesan dari gambar.

Cara unsur rupa itu bekerja dapat diuraikan melalui beberapa tahap. Pertama, anak menangkap objek atau tokoh utama pada gambar. Selanjutnya anak memperhatikan cara objek atau tokoh itu digambarkan agar aktivitasnya dapat diceritakan. Cara penyusunan beberapa objek atau tokoh pada satu layar ditangkap anak agar bisa diceritakan (seorang tokoh digambar tujuh kali, untuk menunjukkan tokoh itu penting.

2. Temuan tiga gaya tutur dan pendampingan berjenjang. Didapat melalui perbandingan hasil pengamatan penuturan anak TK di lapangan dan verifikasi guru kelas anak yang bersangkutan.

Hasil pengamatan 244 anak TK A-B berdasarkan hasi penuturan anak dan verifikasi guru kelas adalah $55 \%$ anak bergaya sesuai standar (SS), $17 \%$ anak perlu motivasi (PM), dan $48 \%$ anak mampu mengembangkan cerita (MC).

Temuan pendampingan dan gaya tutur ini diperoleh dengan mempertimbangkan gaya tutur dan tingkat pendampingan 1-3 sesuai dengan tingkat kesulitan tiap anak.

Pertama, gaya tutur MC perlu pendampingan tingkat satu. Pendamping menjaga alur.

Kedua, gaya tutur SS perlu pendampingan tingkat dua. Pendamping mengkostruksi dan mengarahkan.

Ketiga, gaya tutur PM perlu pendampingan tingkat tiga. Pendamping perlu memotivasi anak lebih intensif dibanding anak dengan gaya SS atau MC.

3. Temuan tiga model komunikasi gambar pada buku belajar baca anak.

Secara umum model komunikasi gambar bercerita melibatkan tiga pihak, gambar bercerita sebagai pembawa pesan aktif, anak sebagai penatap gambar dan guru atau orang tua sebagai pendamping. Model pertama diawali pengenalan tokoh. Model dua diawali pengenalan tokoh dan cerita dibalik tokoh. Model tiga tidak diawali pengenalan tokoh dan cerita tetapi diberi tugas pengantar saja. Tiap model memberikan dinamika yang berbeda terutama dari 
masalah waktu yang digunakan untuk pengkondisian di babak awal maupun waktu yang dihabiskan selama anak menatap gambar.

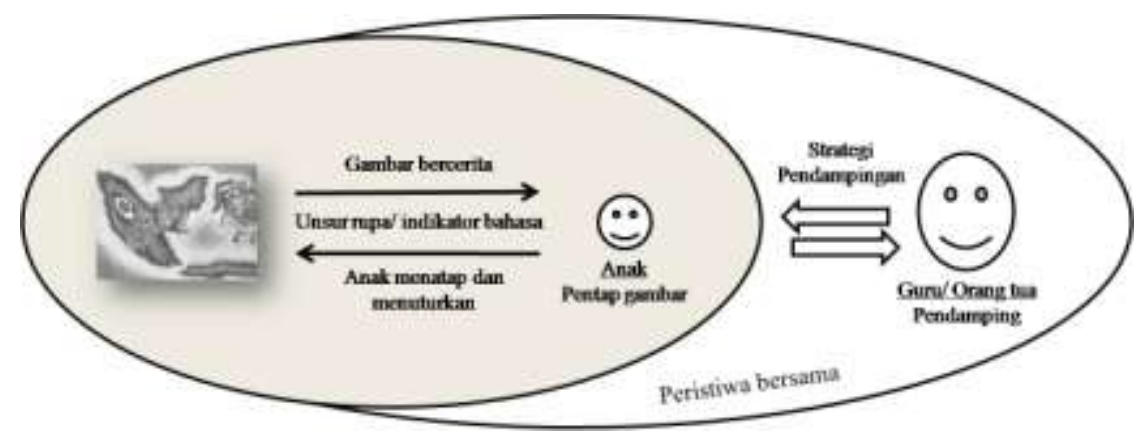

Gambar 7 Model komunikasi gambar dengan anak.

4. Temuan pada ketiga kejadian komunikasi di atas mendorong strategi dan cara pendampingan yang memungkinkan terjadinya kemandirian komunikasi rupa, yaitu proses belajar proses kreasi.

Strategi dan metode ini memiliki prinsip belajar yang mampu mengkondusifkan anak dalam proses komunikasi. Strategi dan metode ini memposisikan pendamping sebagai fasilitator dan motivator. Salah satunya menjalankan komunikasi konstrukstif tanpa boleh memberitahu jawaban.

Berikut adalah strategi antara anak dan pendamping, yaitu:

- Anak melakukan persiapan, pendamping melakukan cerita partisipatif di babak awal

- Anak menemukan masalah, pendamping melakukan pertanyaan yang mendorong rasa ingin tahu anak

- Anak mengumpulkan informasi unsur rupa, pendamping melakukan motivasi bertingkat

- Anak menemukan hubungan, pendamping memberi waktu merenung

- Anak membuat alternatif jawaban, pendamping melakukan percobaan

- Anak mengkonfirmasi jawaban, pendamping melakukan tanya jawab

- Anak membuat kesimpulan akhir, pendamping melakukan motivasi penuturan

5. Aktivitas anak menatap gambar perlu diamati menggunakan indikator bahasa rupa. Indikator anak menatap gambar ini diperlukan untuk mengetahui perkembangan bahasa rupa anak sesuai tahapan yang sesuai usia anak. Indikator bahasa rupa anak saat menggambar adalah hasil temuan Tabrani, penelitian ini menemukan bahwa bahasa rupa anak TK (4-6 tahun) 
yang mampu ditatap anak dari gambar bercerita berada pada rentang 4-10 tahun. Indikator diperlukan pendamping untuk mengetahui proses anak berbahasa rupa dan tutur sesuai kemampuannya. Indikator rupa diperlukan untuk memantau kemampuan anak mengkonstruksi unsur rupa pada gambar. Indikator berbahasa tutur diperlukan untuk memantau kemampuan anak menuturkan isi pesan, mendengarkan pengenalan tokoh dan cerita partisipasi di babak awal dan motivasi yang diberikan pendamping.

Indikator ini ditemukan melalui pengamatan proses anak menatap gambar yang dievaluasi menggunakan perkembangan bahasa rupa anak Tabrani 4-10 tahun dan standar perkembangan berbicara dan mendengarkan dari Paud Diknas.

\section{$5 \quad$ Kesimpulan}

Penggunaan bahasa rupa anak menjadi hal yang penting dalam kejadian komunikasi gambar bercerita. Dari sisi anak, bahasa rupa anak digunakan sebagai sistem komunikasi yang dipahami anak ketika ia mengkonstruksi unsur rupa gambar menjadi pesan yang dipahami sampai ia mampu menuturkannya.

Dari sisi gambar, bahasa rupa anak digunakan sebagai cara gambar menyampaikan ceritanya melalui cara gambar dan cara susun seluruh unsur rupa yang ada pada gambar agar dapat ditangkap ceritanya. Dinamika tersebut menunjukkan pentingnya strategi dan cara pendampingan yang memiliki kemampuan memotivasi dan memfasilitasi kemandirian anak dan gambar dalam berkomunikasi.

Kesimpulan penelitian ini menunjukkan dua hal, yaitu pentingnya gambar bercerita sebagai pembawa pesan aktif dan pentingnya gambar bercerita dan anak berada pada kejadian komunikasi bersama.

Gambar bercerita memiliki dua fungsi, yaitu kemandirian gambar dalam membawa pesan secara aktif dan kemampuan bekerjasama dengan kata dalam proses anak belajar baca. Kekuatan mandiri ini diperoleh dari kemampuan gambar bercerita dalam menuturkan peristiwa dalam ruang dan waktu dalam satu layar.

Unsur rupa dan cara kerjanya inilah yang menunjukkan pentingnya kejadian komunikasi bersama. Bukan persoalan efektivitas pesan, tetapi persoalan dampak dari pentingnya kejadian komunikasi bersama itu. Kejadian komunikasi gambar bercerita menunjukkan kemampuan anak menangkap pesan dan menyatakan kembali pesannya dengan caranya sendiri yang unik dan khas berdasarkan indikator bahasa rupa anak. Demikian juga halnya dengan gambar bercerita yang hanya mampu membawa pesan secara aktif dan mandiri bila ia 
berada pada kejadian bersama dengan sistem komunikasi yang sama yaitu bahasa rupa anak.

Penelitian ini menyimpulkan tiga model komunikasi gambar bercerita dengan dinamikanya sendiri. Model pertama diawali pengenalan tokoh saja. Model dua, diawali pengenalan tokoh dan cerita seputar karakater dan asal usul tokoh. Model tiga tidak diawali pengenalan tokoh dan cerita. Model yang paling ideal adalah model kedua, dengan syarat pendamping harus bisa menjaga aturan main dalam jalur kemandirian anak menatap gambar. Alasannya model ini didahului aktivitas bercerita dengan pengenalan tokoh yang interaktif dan partisipatif yang membuat anak merasa aman dan nyaman untuk mengurai unsur rupa pada gambar dan menuturkannya. Model lain bisa digunakan sepanjang dinamika di dalamnya dipahami dalam pelaksanannya.

Dengan demikian pengetahuan model komunikasi gambar bercerita memiliki manfaat pada saat anak belajar menangkap pesan dan menuturkan pesannya secara mandiri dengan tiga gaya tuturnya yang khas, baik sesuai standar bahasa rupa, mengembangkan cerita atau anak yang perlu motivasi lebih.

Strategi yang paling tepat digunakan pada komunikasi gambar bercerita ini adalah strategi proses belajar proses kreasi. Sementara Cara belajar yang anak yang paling cocok adalah Cara Belajar Kreatif (CBK). Strategi dan metode ini memiliki prinsip belajar yang mampu mengkondusifkan anak dalam proses komunikasi. Salah satunya yang penting adalah guru bertanya anak menjawab. Strategi dan metode ini memposisikan pendamping sebagai fasilitator dan motivator. Salah satunya menjalankan komunikasi konstrukstif tanpa boleh memberitahu jawaban.

\section{Ucapan Terima Kasih}

Terima kasih tak terhingga buat dua orang dosen pembimbing yang selalu memberi nasehat dan arahan penelitian yang terstruktur. Dr. Priyanto Sunarto dan Dr. Pindi Setiawan M.Si. Terima kasih juga bagi reader, Dr. Intan Rizky M.Sn yang bersedia membaca dalam tempo yang sangat optimal dengan kesungguhan yang berdedikasi. Penguji yang saya hormati Ifa Safira Sagir M.Si dengan pertanyaan yang menggugah. Teladanku, Prof Dr. Primadi Tabrani yang bersedia meluangkan waktu dan hatinya untuk komentar yang kritis dan masukan perubahan yang membangun. Pemimpinku, Drs Rizki Akhmad Zaelani dengan prinsip-prinsipnya yang kuat dalam mengarahkan spirit selama studi. Semoga Allah senantiasa memberi mereka kesehatan, panjang umur dan semangat juang yang tak pernah padam. 
Terutama buat anak-anak usia dini yang bersedia terlibat dalam pengalaman pengamatan selama empat tahun di TK Bumi Limas dan penelitian singkat di empat TK di Bandung Timur. Semoga menjadi generasi masa depan yang senang berimajinasi, kreatif dalam menatap gambar dan membaca untuk melakuan perubahan yang lebih baik.

\section{Referensi}

[1] Departemen Pendidikan Nasional. 2005. Kurikullum 2004 Standar Kompetensi, Jakarta, Cetak terbatas Departemen Pendidikan Nasional Direktorat Jendral Manajemen Pendidikan Dasar dan Menengah.

[2] Tabrani, Primadi. 2009. Wimba, Asal Usul dan Peruntukkannya, Jurnal Wimba, KK KVMM FSRD, 1, pp. 1-6.

[3] Fiske, John. 2004. Cultural and Communication Studies, Yogyakarta, Jalasutra.

[4] Tabrani, Primadi. 2005. Bahasa Rupa, Bandung, Penerbit Kelir.

[5] Arnheim, Rudolf. 1997. Visual Thinking, London, University of California Press.

[6] Tabrani, Primadi. 2006. Kreativitas dan Humanitas, Bandung, Penerbit Jalasutra. 